\title{
Spatio-Temporal Declines in Philippine Fisheries and its Implications to Coastal Municipal Fishers' Catch and Income
}

\section{OPEN ACCESS}

Edited by:

Maria Lourdes D. Palomares, FishBase Information and Research

Group, Inc., Philippines

Reviewed by:

David Jonathan Mills, University of Tasmania, Australia Simon Foale,

James Cook University, Australia

Roehlano Mariano Briones, Philippine Institute for Development Studies, Philippines

*Correspondence: Jonathan A. Anticamara jonathan.anticamara@gmail.com

Specialty section:

This article was submitted to Marine Fisheries, Aquaculture and

Living Resources, a section of the journal Frontiers in Marine Science

Received: 21 October 2015

Accepted: 15 February 2016 Published: 02 March 2016

Citation:

Anticamara JA and Go KTB (2016) Spatio-Temporal Declines in Philippine Fisheries and its Implications to Coastal Municipal Fishers' Catch and

Income. Front. Mar. Sci. 3:21

doi: 10.3389/fmars.2016.00021

\author{
Jonathan A. Anticamara ${ }^{1 *}$ and Kevin T. B. Go ${ }^{1,2}$ \\ ${ }^{1}$ Institute of Biology, University of the Philippines Diliman, Quezon City, Philippines, ${ }^{2}$ College of Marine and Environmental \\ Sciences, James Cook University, Townsville, QLD, Australia
}

The problem of overexploitation in global fisheries is well-recognized. However, published assessment of fisheries spatio-temporal trends at the national scale is lacking for many high biodiversity developing countries, which is problematic since fisheries management is often implemented at the local or national levels. Here, we present the long-term spatio-temporal trends of Philippine fisheries production based on the landed national fish catch data (1980-2012) and fishers' interviews. We found that the total Philippine fish catch volume (Metric Tons MT) of most capture fisheries throughout the country has either stagnated or declined over the last three decades. The decline is even more prominent when evaluating fisheries trends at the provincial level, suggesting spatial serial depletion of the country's fisheries. In contrast, the total Philippine fish catch value (US Dollars US\$ or Philippine Pesos PHP) has continued to increase over time, despite the declining fish catch volume. However, local municipal fishers are experiencing both low fish catch and income, contributing to observable poverty in many coastal communities in the Philippines. The various stakeholders of Philippine fisheries need to recognize the depleted state of Philippine fisheries, and learn from various experiences of collapsed and recovered fisheries from around the world, in order to recover the Philippines' capture fisheries. Lessons from the literature on collapsed fisheries offer the following options for recovery: (1) regulate or reduce fisheries exploitation and other human activities impacting the fisheries to allow fisheries to rebuild or recover, (2) enforce effective networks of marine reserves, (3) engage fishers, consumers, and other stakeholders in fisheries management, (4) improve fisheries science, monitoring, and management capacities, and (5) provide alternative livelihood, skills, and improved education to fishers and their families.

Keywords: fish catch data, fishers' economics, fisheries management, fisheries production, overfishing

\section{INTRODUCTION}

The state of global fisheries is continuously declining, with catch rates falling since the 1980's (Pauly et al., 2002). Despite this declining trend in fisheries production, global fishing effort has been continuously increasing (Anticamara et al., 2011). The world's fisheries have resorted to geographic, bathymetric, and taxonomic expansion to cover for declining catches in overexploited fishing grounds (Pauly, 2009). Catches for most trophic levels are still rising, potentially contributing 
to increasing fisheries collapse (Branch et al., 2010). To date, the global catch biomass of large predatory fish is estimated to be between 10\% (Myers and Worm, 2003) and 60\% (Juan-Jorda et al., 2011) of pre-industrial fishing levels, with most stocks fullyexploited, limiting further expansion of these important fisheries. Furthermore, FAO (2012) reported that in 2009, 57.4\% of global fish stocks were fully-exploited, $29.9 \%$ were overexploited, and only $12.7 \%$ were non-fully exploited.

Monitoring and managing fisheries status throughout the globe is essential in maintaining their sustainability, or, in the case of depleted fisheries, facilitating their recovery (Pauly, 2009). Fisheries monitoring and management is typically carried-out at the national or regional level, most of which is being done in developed parts of the world such as North America, Oceania, and parts of Europe (Musick et al., 2000; Jelks et al., 2008). However, more attention must be given to developing nations that exhibit high marine biodiversity and increasing fish catch (i.e., suggesting increasing fishing activity), but often report patchy fisheries data and analysis to FAO or the scientific literature (i.e., data poor countries; Worm and Branch, 2012).

The Philippines, a nation considered to be a major hotspot of marine biodiversity (Roberts et al., 2002), currently lacks quantitative analysis on the long-term, spatio-temporal trends in its national fisheries production. Comprehensive national-scale studies on the trends of Philippine fisheries exist, but focused on particular fisheries sub-sectors (e.g., artisanal fisheries; Muallil et al., 2014a,b), policy and management (Briones, 2007), or total national production only (Sadovy, 2005). Currently, the Bureau of Fisheries and Aquatic Resources (BFAR) in the Philippines is the authority on monitoring the status and productivity of Philippine fisheries. However, the annual Fisheries Profile publications produced by BFAR (accessible at: http://www.bfar. da.gov.ph/, accessed 1 August 2015) typically review only shortterm trends in fisheries production (i.e., changes in fisheries production from the past 2 or 3 years).

The lack of long-term analysis on Philippine fisheries is surprising, considering the socio-economic importance of fisheries and fishing activities to the country. The Philippines is among the top 15 nations in global marine fisheries capture production (FAO Fisheries Aquaculture Department, 2014), and many Filipinos depend on fish products for both food and livelihood-i.e., Filipinos derive an estimated $43 \%$ of their animal protein diet from fish and fish products (FAO, 2001), and over 1.6 million Filipinos were employed in fisheries-related occupations based on 2011 data (BFAR, 2011).The demand for fish products will only increase with time, as the Filipino population has been growing at an average rate of $1.9 \%$ from 2000 to 2010, with 2010 population estimates to be at over 92.3 million individuals (NSO, 2014). Thus, there is a great need to examine the Philippine's fisheries trends and its possible implications, in order to help drive science or data-based decision-making in the management of the nation's fisheries.

This study presents the most recent spatio-temporal analysis of Philippine fisheries production based on landed national fish catch and fishers' interview data. The objectives of the study are the following: (1) to quantify the spatio-temporal trends in Philippine fisheries production from 1980 to 2012; (2) to present the estimates of fishers' fish catch and income from five Philippine fishing provinces; and (3) to explore options and insights for improving the science and management of Philippine fisheries through a literature review focused on the most recent research on fisheries status assessments and recommendations for declining fisheries.

\section{METHODS}

\section{Spatio-Temporal Trends in Philippine Fisheries Production}

To analyze the long-term, spatio-temporal trends in Philippine fisheries, we obtained online fisheries data from BFAR, the Philippine government institution, which currently collects and maintains the most complete and up-to-date national database on Philippine fisheries production. However, the online data provided by BFAR is strictly fisheries-dependent (i.e., based on fish catch or landings). Relying solely on catch data to assess fisheries has been criticized as being misleading in estimating the actual status of fish stocks (Branch et al., 2011). Nevertheless, for developing countries such as the Philippines (which lacks the infrastructure and funding to consistently conduct expensive national-scale fisheries-independent surveys), monitoring fish catch data is often the only feasible method of assessment and most readily-available data source (Pauly et al., 2013). In addition, Froese et al. (2012) showed that fish catch data are consistent with trends in biomass data of fully-assessed stocks (i.e., those stocks assessed by fisheries-independent methods), refuting claims on the limited usefulness and misleading nature of fisheries-dependent data.

We also obtained Philippine national fisheries data from BFAR's annual Fisheries Profile publications, from 1980 to 2012 (accessible at: http://www.bfar.da.gov.ph/, accessed 1 August 2015). Each annual Fisheries Profile publication contains information on the country's total fisheries production and trade of aquatic resources and top fisheries products for that year. Philippine fisheries data for the years 2013 and 2014 are not yet available to date.

We plotted the temporal trends (from 1980 to 2012) of Philippine fisheries production volume (fish catch in Metric Tons or MT) and value (converted from Philippine Pesos PHP to US Dollars US\$; conversion rate was $43.57 \mathrm{PHP}=1$ US\$ as of 5 Aug 2015), for total national production (i.e., all fisheries sectors combined), and production per sector (i.e., commercial fisheries sector, marine municipal fisheries sector, inland municipal fisheries sector, and aquaculture sector). We also examined the mean ( \pm standard error SE) fisheries production between successive decades-i.e., 1980-1989, 1990-1999, 2000-2009, and 2010-2012 (henceforth referred to as the 1980's, 1990's, 2000's, and 2010's, respectively) - using one-way ANOVA and Tukey's post-hoc analysis.

We then focused our subsequent analysis on the spatiotemporal trends in the marine municipal fisheries sector. We extracted data on marine municipal fisheries fish catch landings (in MT) from the CountrySTAT Philippines database (accessible at: http://countrystat.psa.gov.ph/, accessed 1 August 2015), which 


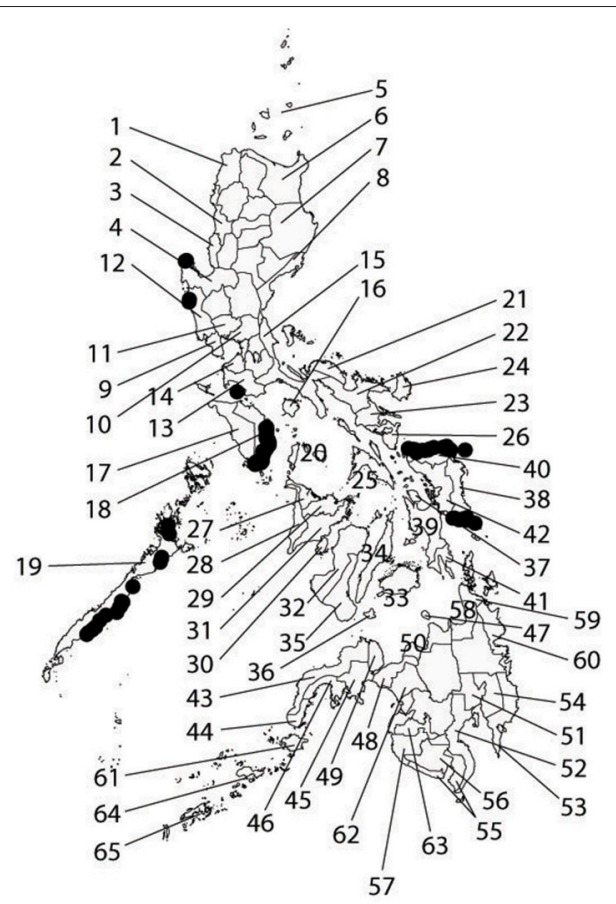

FIGURE 1 | Map showing sources of provincial municipal fish catch data (numbers), and fisher interview sites (dark circles). List of provinces with their corresponding number codes are listed in Table S1.

sources fish catch data from the Bureau of Agricultural Statistics. Fish catch data is presented as total sum per province. The goal of this analysis is to determine the contributions of each province to Philippine fisheries, and whether the marine municipal fisheries per province showed signs of increasing or decreasing production from 1980s to date. Provinces included in the analysis are shown in Figure 1. Province names corresponding to each province code are shown in Table $\mathrm{S} 1$.

\section{Status of Municipal Fishers' Catch and Income}

To present the status of Philippine fisheries at the level of the fishers themselves, we interviewed a total of 470 coastal municipal fishers from 84 coastal villages or barangays belonging to 17 municipalities throughout the Philippines (Figure 1). Here, we focused our analyses on the 470 fishers from the municipal marine fisheries sector, due to the following reasons: (1) majority (over 90\%) of the fishers in the villages that we visited were coastal municipal fishers (i.e., municipal waters defined as $15 \mathrm{~km}$ away from the mainland as defined by the Philippine Republic Act 8550) and only few were commercial and off-municipal water fishers; and (2) coastal resource management and legislation in the Philippines is typically enforced at the municipal level (i.e., within the boundaries of municipal waters).

Fishers' interviews were conducted from July 2013 to July 2014. Interviews were conducted one-on-one, where fishers were asked questions regarding their estimated fish catch, fishing effort, and income from fishing. Interviewees were selected at random, or referred by previously-interviewed fishers.
Interview data was used to plot the mean \pm SE fish catch volume (in $\mathrm{kg}$ ), catch value (in US\$), and fuel cost (in US\$) per hour per fisher. We standardized catch data and fuel expenses to per hour because the amount of time spent fishing was highly variable between fishers. Most coastal fishers in the Philippines use multiple gears and switch gears during a single fishing trip, so we ignored gear types in current analysis and focused on the overall catches and incomes regardless of gears used, for as long as they fished within municipal waters. To compute for fuel cost per fishers, we multiplied each fisher's estimated fuel consumption with mean common gas price estimates for the year 2013 (i.e., estimates taken from the Philippine Department of Energy, accessible at: https://www.doe.gov.ph/oilprice-monitoring, accessed 1 August 2015).

\section{Review of Relevant Fisheries Literature on Fisheries Status, Collapse, and Options for Recovery}

We reviewed the published peer-reviewed fisheries status assessment literature to determine the following: (1) how many publications reported global or national assessment of fisheries trends; (2) what data types were used in published global or national fisheries assessments; (3) what were the trends in status or spatio-temporal dynamics in assessed fisheries; (4) what were the identified consequences of the observed fisheries trends; (5) what were the drivers of the observed fisheries trends; and (6) what actions were recommended or implemented to recover declining fisheries (assuming that those recommendations were based on the understanding of various authors on the best or effective ways to address fisheries decline).

To conduct the literature review, we used the Web of Science Core Collection online database and queried all literature from 2009 to 2014 (past 5 years) using the search parameters "[marine* AND fishery*]" (accessed March 2014). This initial search yielded nearly 2000 papers, but was filtered to only include studies that presented assessments of target fisheries status (i.e., studies that focused on the structure of management or socio-political factors driving fisheries without quantifying fisheries status were not included). Modeling papers where empirical data was used to present specific case studies were also included. We also included studies that did not explicitly measure the effectiveness of fisheries management strategies for as long as they presented fisheries status assessment, because the main purpose of the literature review was to explore the findings of recent fisheries assessments, rather than to quantify management effectiveness. We separately presented assessment studies on global fisheries (Table S2), and national fisheries (Table S3). Because of the large variation in data types, consequences, drivers, and recommendations provided by authors, we categorized each entry for presentation in the Supplementary Tables. For example, under the recommendations column, "Regulate fishing activity" may refer to any of the following: Total Allowable Catch TAC establishment; fishing quotas; gear restrictions; policing against IUU; fishing vessel limits; and fishing closure seasons. Further details on each category can be found in Table S4. Out of the initial 2000 publications we only included in our review a total of 


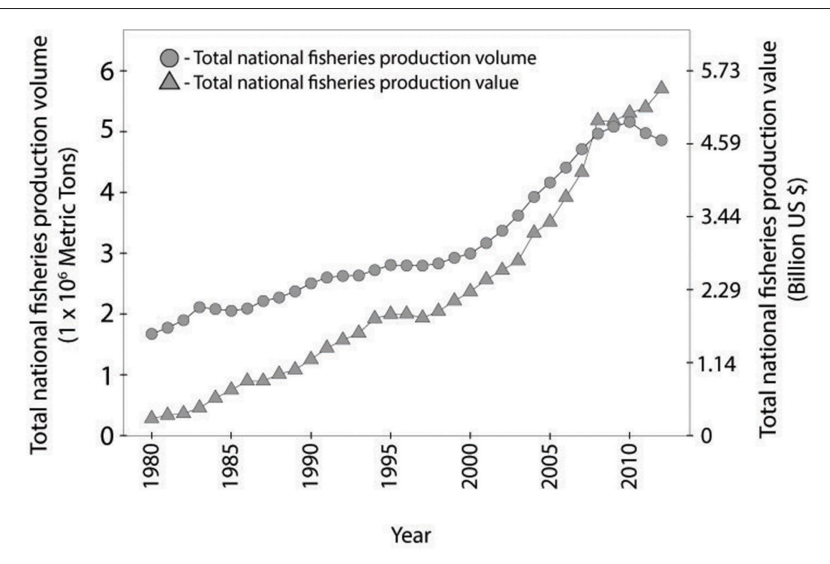

FIGURE 2 | Time-series data of total Philippine fisheries production volume and value from the years 1980-2012.

56 peer-reviewed publications that actually documented fisheries status at global or national scales. The rest of the publications mainly focused on various aspects of fisheries such as sociopolitical and economic issues, management issues, by-catch problems and estimates, etc.

\section{RESULTS AND DISCUSSION}

\section{Spatio-Temporal Trends in Philippine Fisheries Production}

The total landed Philippine fish catch volume showed a generally increasing trend from 1980 to 2010, followed by a decline in production from 2010 to 2012 (Figure 2). In contrast, total landed Philippine fish catch value showed a continuously increasing trend from 1980 to 2012 (Figure 2). The sector that contributed most to total Philippine fisheries production over the last three decades, in terms of both volume and value, was the aquaculture sector (although most of this was seaweed, which contributed on average about $56 \pm 2.8 \%$ of total aquaculture production volume per year), followed by the marine municipal fisheries, commercial fisheries, and inland municipal fisheries sectors, respectively (Figure 3). One-way ANOVA and Tukey's post-hoc analysis showed that aquaculture production volume continued to increase significantly between successive decades from the 1980's up to recent times (Figure S2). In contrast, the capture fisheries sectors (e.g., municipal and commercial sectors) showed slight or non-significant increase in production volume since the 2000's, suggesting a stagnation in fish catch. However, the production values of all fisheries sectors continued to increase between successive decades from 1980's to recent times (Figure S3).

The top five provinces that contributed most to marine municipal fisheries production volume from 1980 to 2012, arranged in descending order, were Palawan, Zamboanga del Norte, Iloilo, Negros Occidental, and Surigao del Nortewhile the rest of the other provinces contributed much smaller fisheries production volume (Figure 4). A large portion of marine municipal fish catch over the past decade was due to Palawan,

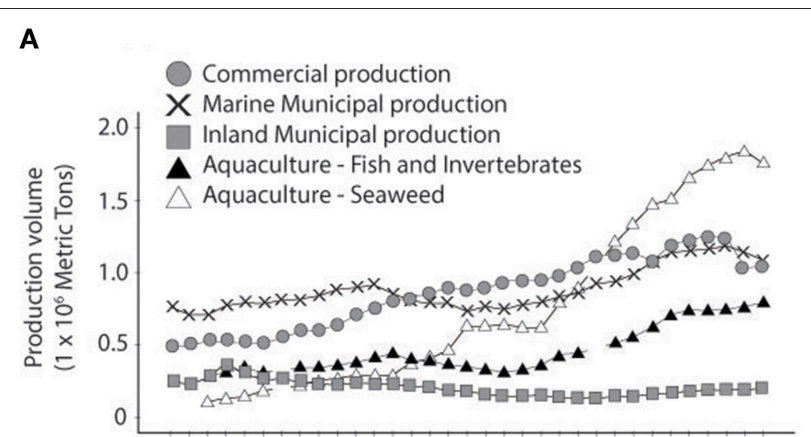

B

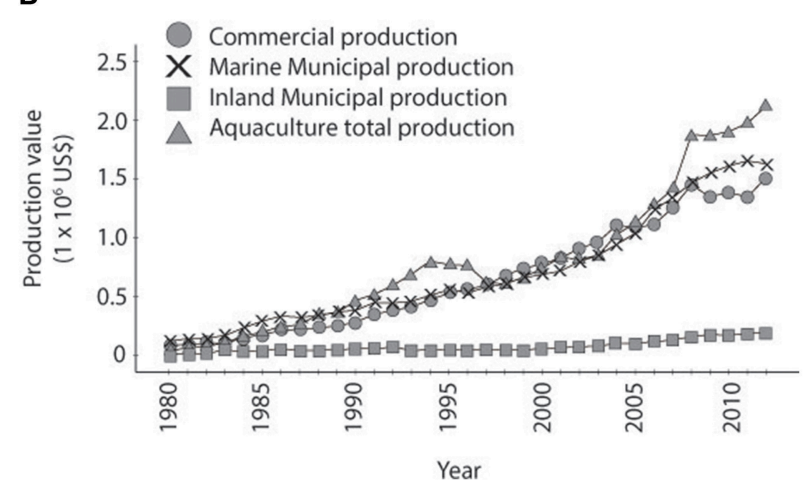

FIGURE 3 | Time-series data of Philippine production volume (A) and value (B) per sector from the years 1980-2012.

which showed a steep increase in production volume from the year 2000 until 2006, after which its production volume began to drop continuously until 2012. Similarly, Zamboanga del Norte and Negros, two more provinces belonging to the top five marine municipal fisheries producers, experienced noticeable drops in production volume in the late 1980's and early 1990's, respectively, with production failing to return to previous levels ever since. When we examined decadal trends in production volume, we found that $75 \%$ of the 65 provinces showed no significant increase in fish catch since the 2000's, suggesting that municipal fish catch has stagnated in those provinces over the last decade (Figure 4, Figure S1, Table S1).

Our examination of long-term, spatio-temporal data of Philippine fisheries reveals that capture fisheries have either stagnated or declined in terms of production volume. The bulk of total production volume of Philippine fisheries since the 2000's has been mainly supplied by aquaculture (albeit mainly seaweeds), rather than wild fish catch, and the country's municipal fish catch is sustained by only a few provinces. Stagnating capture fisheries in the Philippines is a matter of economic and ecological concern, since low wild fish catch could be an indication of depleted fish stocks. Fish catch may not always be an accurate reflection of fish stock status, particularly under conditions of effective management, wherein declines in fish catch records are due to the effectiveness of policies that limit fishing (e.g., enforcement of Total Allowable Catch quotas (TACs) and Marine Reserves (MRs)). However, given the lack 


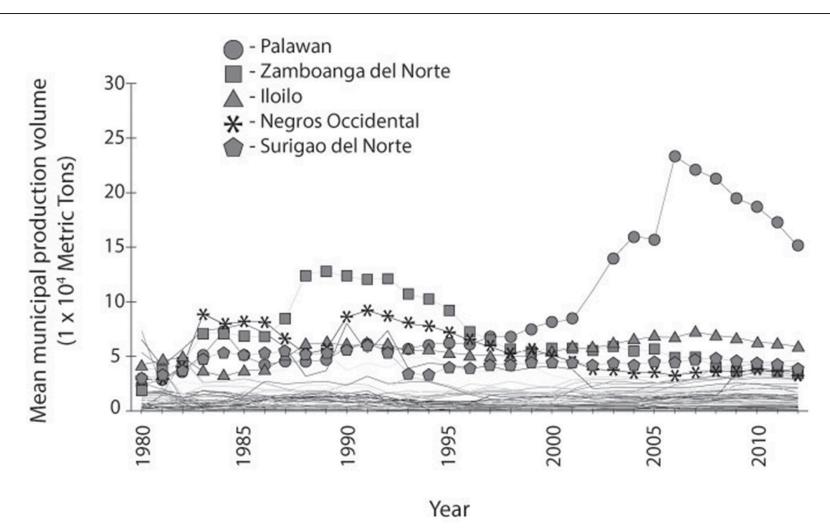

FIGURE 4 | Time-series data of Philippine marine municipal fish catch highlighting the top five fish-producing provinces (indicated by symbols and legends) from $\mathbf{1 9 8 0}$ to $\mathbf{2 0 1 2}$. Other provinces are represented as lines without symbols, and generally showed much lower fisheries production than the top five provinces.

of enforced fisheries management and the high exploitation rate in many Philippine reefs and coastal areas (Alcala and Russ, 2002; Muallil et al., 2014b), we doubt that the decrease in fish catch recorded in Philippine waters is due to effective fish catch restrictions and management (with the exception of a few wellenforced MRs in the country). Instead, we highly suspect that the decrease in fish catch perhaps reflects the depleted and overexploited status of many Philippine fish species, particularly commercially-important, large-bodied reef fish species (Go et al., 2015).

Previous studies have lamented the un-sustainability of most Philippine fisheries (Sadovy, 2005; Stobutzki et al., 2006; Muallil et al., 2014b). Once exploitation rate exceeds a certain threshold, the number of collapsed species increase, and declines in total fish catch, fish stock biomass, and mean fish body size follow (Worm et al., 2009). Our analysis suggests that Philippine fisheries may indeed be overexploited; fish catch has not increased overtime (and in fact, has decreased for several provinces), despite continuously increasing fishing effort in the country (Briones, 2007), and the increasing number of registered municipal and commercial fishers in the Philippines (according to BFAR's annual Fisheries Profile publications 1980-2012). Evidence in other studies also point to Philippine fisheries' un-sustainability, with most authors citing overfishing as a major factor in the declines of Catch Per Unit Effort (CPUE), catch biomass, diversity, and shifts in fish community structure observed in Philippine waters (Silvestre et al., 2003; Stobutzki et al., 2006; Muallil et al., 2014a; San Diego and Fisher, 2014).

Despite recent declines in fish catch, the value of Philippine fisheries has continued to increase significantly over the last three decades. This could suggest that the market price of fish throughout the country is generally increasing - an effect of the high demand for fish brought about by the growing Filipino population and the declining fish catch in Philippine waters. Increases in the price of fish products could also be due to the increasing cost of fishing itself. For example, fishers may be exerting greater fishing effort (e.g., by spending more time and fuel fishing or investing in more expensive fishing technology) to compensate for the declining abundance of fish in most coastal areas. Increased costs of fishing, combined with declining fisheries production, will undoubtedly have negative effects on the resource's primary users, the fishers.

\section{Fishers' Fish Catch and Income}

The declining fish catch of Philippine capture fisheries is reflected in the low income of most municipal fishers. Based on our interview data, mean fish catch of the average Filipino municipal fisher was $1.87 \pm 0.14 \mathrm{~kg} / \mathrm{h}$ (Figure 5A). Mean catch value of interviewed fishers was $1.7 \pm 0.1 \mathrm{US} \$ / \mathrm{h}$ (Figure 5B), but their mean fuel cost was $0.4 \pm 0.0$ US $\$$ per h (Figure 5C). After conversion to daily estimates, we found that the average Filipino fisher earns only about 12.4 US\$ from fishing per day (with a mean of $7.3 \pm 0.2$ fishing hours per day, based on interviews). By factoring-in their daily fuel cost of about 2.9 US\$ after $7.3 \mathrm{~h}$ of fishing, it becomes apparent that most fishers are left with less than 10.0 US\$/day, a value comparable to that found by Muallil et al. (2014b). This amount is hardly enough to pay for a fisher's daily expenses, especially considering that interviewed fishers had an average of $3.3 \pm 1.5$ dependents to support, in addition to their own personal expenses ( $n=160$ respondents with dependents). Furthermore, fishers generally do not fish every day, or throughout the year (mean of $19.8 \pm 0.4$ fishing days per month, and $9.7 \pm 0.3$ fishing months per year based on interviews), and $61 \%$ of the interviewed fishers $(n=303$ respondents) did not have any alternative livelihoods other than fishing.

The low fish catch and income of most fishers, in addition to their over-reliance on fishing as a livelihood, has contributed to the extreme poverty in many Philippine coastal communities. The extreme poverty and continued overexploitation observed in many coastal fishing communities throughout the Philippines is indicative of Malthusian overfishing, wherein per capita fish catch (and subsequently, income) declines over time, as fishers continue to overexploit a rapidly-degrading resource (Pauly, 1990). To alleviate resource degradation, the responsibilities and costs of coastal resource management in the Philippines typically fall to multiple stakeholders. These stakeholders include the following: (1) the municipal Local Government Units (LGUs), who have the political power to establish and enforce coastal management policies based on Philippine Republic Act 8550 (e.g., enforcement of MRs, bans on destructive fishing methods, or implementation of fishing area zoning), (2) national government agencies such as the Bureau of Fisheries and Department of Environment (3) the fisher communities themselves, who have the responsibility to follow and participate in fisheries policy implementation, (4) the donor agencies and non-government organizations, and (5) the consuming public and the fisheries business sectors. However, enforced and sustainable coastal resource management is lacking in many Philippine coastal communities. In addition, fishers have little incentive to support coastal resource management efforts, partly because of the lack of alternative and because equitable distribution of management benefits (e.g., increased fish catch and income) is rare (Christie et al., 2005; but see further 


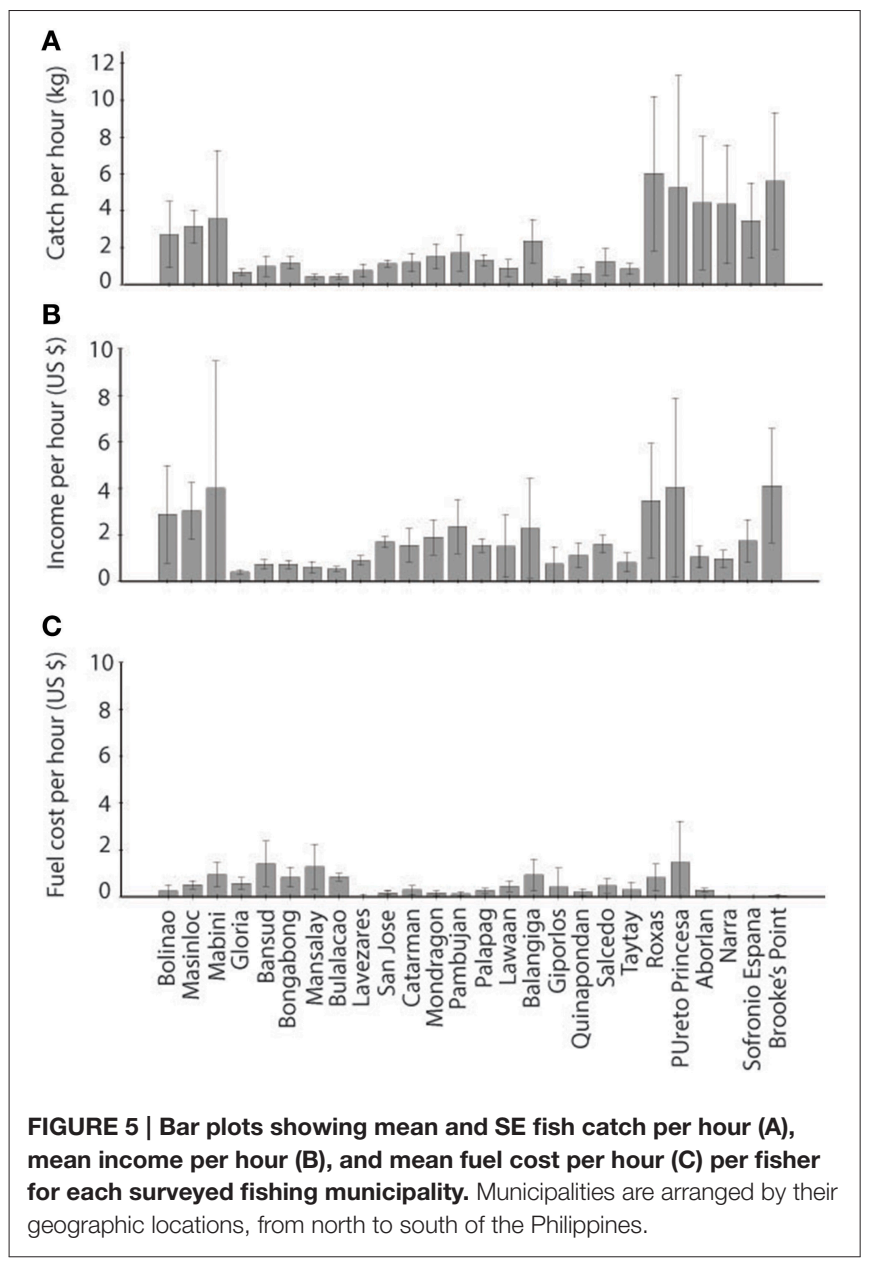

discussions below). However, the various Philippine fisheries stakeholders need to (1) recognize the depleted state of Philippine fisheries, and (2) learn from experiences of collapsed and recovered fisheries from around the world, in order to help improve the current state of Philippine fisheries. Otherwise, maintaining the current status quo will depress the fisheries further and will put all stakeholders at a disadvantage-i.e. the fishers (in terms of lost livelihood and income), the government (in terms of lost fisheries rent), and the consuming public (in terms of lost availability of fish food). There is a great need to further explore the sharing of management costs and benefits to improve current conditions of declining Philippine fisheries by the various concerned stakeholders.

\section{Review of Relevant Literature on Fisheries Trends and Options for Fisheries Recovery}

Many of the publications we reviewed documented declining or potentially-declining fisheries across the globe (73\% of 56 studies; Tables S2, S3). Only 20\% of studies reported stable or recovering fisheries, while $7 \%$ gave mixed interpretations on the status of the studied fisheries.

Of the 41 studies that reported declining or potentiallydeclining fisheries, the most documented consequences were declining fish catch biomass (73\% of 41 studies), poor status of evaluated fish stocks (51\%), and low or declining fish catch diversity (39\%). Overfishing was the most cited driver of declining fisheries ( $80 \%$ of 41 studies), which includes IUU, increases in fisher population, and implementation of subsidies that increase fishing pressure (e.g., by providing more boats or fishing gear to fishers). Anthropogenic disturbance was the next most cited driver (20\%), followed by natural causes (14\%). In contrast, many of the studies that documented stable or recovering fisheries reported high or increasing fish catch biomass (64\% of 11 studies), good fish stock status (45\%), good fish diversity (27\%), and economic gains associated with fishing (27\%). The most cited driver of these stable fisheries was implementing strategies that regulated fishing activity (91\%), mainly through the establishment of fishing quotas, fishing closures, MRs, and policies against illegal fishing. Such strategies are mainly applied in the context of developed countries, but to date have been challenging for developing countries (including the Philippines) to apply because of the associated costs of research and expertise, assessment, management implementation and enforcement, and the costs of providing alternative livelihoods for fishers displaced by management implementation.

Most studies, whether reporting declining or stable fisheries, recommended some form of management for fisheries recovery and sustainability ( $87 \%$ of 56 studies). Among the 49 studies that provided management recommendations, the most frequent suggestion was the direct regulation of fishing activity (71\% of 49 papers). Direct regulation of fishing activity could be done through a variety of methods, including the implementation Total Allowable Catch (TACs), fishing quotas, gear restrictions, policing against IUU, fishing vessel limits, fishing closure seasons, fishing permits or licenses, and carefully-implemented fisheries subsidies (i.e., subsidies that do not lead to increased fishing pressure). Among these options, establishment of MRs, gear restrictions, and policing against IUU may be realistically applied to Philippine fisheries management today (though enforcing these policies may be challenging, considering the high costs of management implementation and the spatial variability of multi-gear and multi-species fishing activity in most Philippine coastal areas, Muallil et al., 2014a). Other methods, such as TACs and quotas, are set by data-intensive stock assessments and monitoring that require consistent funding and institutional support-which coastal resource management bodies (e.g., municipal LGUs) in the Philippines generally lack. However, conducting such data-driven assessments is imperative to improve the management of Philippine fisheries, and hopefully, the Philippine government will allocate sufficient funding to cover the costs of fisheries assessment and management in order to rebuild Philippine fisheries and recover the lost fisheries benefits from current overfished and depleted fisheries status. Indeed, the next most frequently-suggested option in the literature was enhancing scientific-based management (40\%), which includes conducting research, stock assessments, and monitoring the status of fisheries and other marine resources, to help make data-driven decisions in coastal resource management. Scientifically, assessed stocks are typically in better condition than unassessed stocks throughout the 
world, as rigorous assessments usually coincide with increased management attention (Hilborn and Ovando, 2014).

Improving collaboration between stakeholders was also suggested (28\%), which means increased transparency and communication between the different levels of management, encouraging co-management, and integrating local knowledge in fisheries assessments and decision-making.

Establishment and enforcement of MRs was also recommended (25\%). MRs have a long history as a management tool in the Philippines, and studies have shown that MRs can increase density and biomass of exploited fisheries species inside MR boundaries through protection of adults (Russ and Alcala, 2004; Samoilys et al., 2007) and self-recruitment (Almany et al., 2007). However, proper enforcement is vital to MR effectiveness (Samoilys et al., 2007), and even long-established MRs can become degraded and depleted when support is lost (Russ and Alcala, 1999, 2003). In addition, few studies have empirically demonstrated the benefits of MRs on surrounding fisheries beyond MR boundaries (Maypa et al., 2002; Russ et al., 2004; Abesamis et al., 2006; Harrison et al., 2012).

Finally, alternative livelihood for fishers (17\%), and increasing stakeholder education and awareness (16\%) were also recommended, particularly by studies conducted in the Philippines. These two recommended management options help improve the economic status of fishers, while simultaneously alleviating fishing pressure. Livelihood diversification decreases the over-reliance of fishers on a single (and highly fluctuating) resource (Allison and Ellis, 2001), while improved education increases fishers' skills and opportunities to enter occupations other than fishing. Thus, alternative livelihoods and improved education are expected to decrease fishing pressure, though the effectiveness of these projects are determined by the type of alternative livelihood provided and the social and demographic background of fishers (Pollnac and Pomeroy, 2005; Muallil et al., 2013). However, many alternative livelihood projects in the Philippines are discontinued after the project's duration expires, because fishers perceived minimal incentive to continue such projects due to a lack of equitably-distributed benefits (Christie et al., 2005; Pollnac and Pomeroy, 2005). In contrast, projects that successfully sustain implementation are those where (1) fishers are actively involved in project planning and implementation, and (2) benefits of alternative livelihoods and other forms of coastal resource management are equitably distributed among stakeholders (Pollnac and Pomeroy, 2005; Pomeroy et al., 2005). While local communities have the responsibility to comply with these management measures, governing bodies have the responsibility to provide adequate incentives toward effective management (Beddington et al., 2007), so regression back to unsustainable practices is prevented. In the Philippines, capacity-building and alternative livelihood programs are implemented by various government and nongovernment institutions, which include stock provision for farming and livestock, technical skills development to increase employment opportunities in other fields, and micro-financing from small business as implemented by the local government and various line agencies (Muallil et al., 2014b). Thus, platforms for encouraging reductions in fishing effort through alternative livelihood programs are taking shape in the country, but need further assessment and improvement, considering the great spatial scale and increasing number of marginalized fishers that rely upon the dwindling fish stocks in most Philippine coastal waters.

\section{Caveats and Future Research}

One of the caveats of the current study is that the data used to analyze Philippine fisheries was limited to fish catch data. Although, fish catch has been criticized as being misrepresentative when analyzing fisheries status (Branch et al., 2011), catch data is currently the most complete, publiclyavailable data type on Philippine fisheries to date. Fish catch data is far from useless, and should be used to infer the status of fisheries wherever it is available, at least tentatively (Pauly et al., 2013). However, stakeholders in Philippine fisheries management should still strive to collect data through fisheries-independent research surveys, monitoring, and stock assessments, which can be used in conjunction with catch data to provide more comprehensive assessments of the nation's fisheries, in the future.

Another caveat is the questionable quality of the Philippine fisheries data. For instance, the existing BFAR database does not take into account Illegal, Unreported, and Unregulated (IUU) fishing. In the Western Central Pacific, which includes the Philippines, it was estimated that IUU comprised $34-38 \%$ of total fish catch from 1980 to 2003 (Agnew et al., 2009). This is a large proportion of catch, and implies that levels of overexploitation in Philippine fisheries may be under-reported. In addition, overlaps between catches of municipal and commercial fishers are largely un-accounted for. Moreover, mobility of fishers and their landings (e.g., movement between provinces) are not clearly accounted for in the database, thus preventing analysis of spatial serial fisheries depletion or geographical expansions. Further, improvement in the quality of Philippine fisheries statistics is essential for better fisheries management applications.

A final caveat of the current study is the inconsistency of Philippine fishing effort records to date. Fishing effort was reported inconsistently in BFAR's annual Fisheries Profile publications from 1980 to 2012, i.e., some BFAR publications reported only the number of registered municipal fishing boats or bancas, while other BFAR publications reported only the number of fishing operators, or registered commercial fishing vessels. In addition, fishing effort data was patchy and not regularly updated. For example, the BFAR Fisheries Profile for the year 2007 presented registered fishing vessel records from the year 1999. Clearly, there is a great need to improve the consistency of tracking fishing effort in the Philippines, in order to monitor the state of the nation's fisheries more accurately.

Future, research on Philippine fisheries should focus on more in-depth analysis of fish catch rates, exploitation levels, and fish stock status recorded in the country. For example, elucidating fish stock status using Underwater Visual Census (UVC) surveys of coastal areas could provide alternative and nondestructive fisheries-independent data collection to complement fish catch records, considering many important municipal fisheries species (e.g., belonging to families Acanthuridae, Caesionidae, Lutjanidae, Lethrinidae, Labridae (particularly 
Scarinae), Nemipteridae, Serranidae, Siganidae, and Kyphosidae) are demersal or reef-associated (Maypa et al., 2002; Abesamis et al., 2006; Muallil et al., 2012, 2014a), and are typically detected by UVC methods. Also, future studies could tap other sources of data not usually accessible online and therefore will be costly to collate. These would include municipal reports, surveys conducted by Non-Government Organizations (NGOs), and the studies of university students and researchers.

In addition, the effects of fisheries management effortswhich include both costs and benefits incurred by all stakeholders involved (Toribio et al., 2013)-should be further explored and analyzed to understand Philippine context of fisheries management. For example, regarding MR establishment, the costs of displacing fishers should be accounted for in addition to the monetary costs of enforcing MR protection (e.g., costs of guardhouse construction, purchase and operations of patrol boats, and costs of manpower to police MRs). Regarding alternative livelihood projects, ensuring the equitable distribution of benefits would give local communities greater incentive to maintain enforced fisheries management, but this also needs to be quantified (Pollnac and Pomeroy, 2005). Such management measures may serve as responses to pressures often faced in developing coastal communities (e.g., overexploited resources, poverty and low income, undernourishment, vulnerability to sudden climactic disturbances), though there are still significant gaps regarding the appropriate responses to particular pressures (Cabral et al., 2013). Thus, there is a great need to study the complexities of fisheries as social-ecological systems (Lebel et al., 2006; Cinner et al., 2012), and to provide specific management recommendations appropriate to the socialecological dynamics of a particular locality or context (Johnson et al., 2013).

Finally, our examination of long-term, spatio-temporal data of Philippine fisheries highlights the need to examine and monitor Philippine fisheries production at finer spatial scales. For example, the high municipal fish catch in only a few provinces (e.g., Palawan) may have masked the overall stagnation or decline of fish catch in most other provinces (Figure 4). Examining fisheries production at finer scales will allow stake-holders and decision makers to apply appropriate management measures based on the spatial variations in Philippine fisheries between different regions, provinces, and municipalities.

\section{CONCLUSION}

Our analysis of Philippine fisheries production suggests that Philippine fisheries production is declining, with the high production volume of the aquaculture sector (i.e., mostly seaweeds) masking the stagnating or declining fish catch of most capture fisheries in recent times. The decline in catch volume of most provincial and municipal fisheries throughout the country is reflected in the low incomes of many Filipino fishers (despite the fact that the total value of capture fisheries continues to increase). Managing fisheries and coastal resources does not end with the implementation of policies that directly influence fishing pressure (e.g., MR enforcement, fishing bans, and catch quotas). Policies related to community management that indirectly influence fishing pressure, such as increasing education levels and providing alternative livelihood to fishers and their families, should be further explored to help reduce the levels of overexploitation experienced by Philippine fisheries. The Philippine media, government, scientific communities, and conservation organizations need to clarify the declining state of Philippine fisheries and explore options to recover or rebuild the overexploited fisheries to meet the needs of rapidly increasing Filipino population.

\section{AUTHOR CONTRIBUTIONS}

JA conceptualized this paper, actively participated in the data gathering, data analysis, and write-up, and set the overall directions for the paper. He also secured the funding for this work. KG gathered the data actively participated in the data gathering, processing, analysis, and write-up. Both authors equally contributed to the development of this paper.

\section{FUNDING}

Office of the Vice Chancellor for Research and Development UP OVCRD (131307 PhDIA), Center for Integrative and Development. Studies UP CIDS, Foundation for the Philippine Environment (FPE), Natural Sciences Research Institute UP NSRI (Project Code: Bio-14-2-05), UP OVPAA Creative Writing Grant, and UP OVCRD/Commission on Higher Education (CHED)-Biodiversity and Resilience (BaR) Project.

\section{ACKNOWLEDGMENTS}

The authors would like to thank the Mayors and Local Government Units and Agencies of all the municipalities included in this research for their support. The authors are also thankful for the support of the Local People's Organizations in Bolinao (Kaisahan ng mga Samahan Alay sa Kalikasan KAISAKA), Masinloc (Samahang Pangkaunlaran ng San Salvador SPSS), and Mabini (Samahang Pangkaunlaran ng San Teodoro SPSTI). Special thanks to the State Universities who helped in this research: Ateneo de Naga (Joanaviva Plopenio and Shane Bimeda), Bicol State University (Karina Luth Discaya, Antonino Mendoza, and Meek Salvador), Mariano Marcos State University (Wilnorie Rasay), Palawan State University (Dr. Michael Pido), University of Eastern Philippines (Dr. Ronelie Salvador and Saula Gabona).

\section{SUPPLEMENTARY MATERIAL}

The Supplementary Material for this article can be found online at: http://journal.frontiersin.org/article/10.3389/fmars. 2016.00021 


\section{REFERENCES}

Abesamis, R. A., Alcala, A. C., and Russ, G. R. (2006). How much does the fishery at Apo Island benefit from spillover of adult fish from the adjacent marine reserve? Fish. Bull. 104, 360-375. Available online at: http://fishbull.noaa.gov/ 1043/1043toc.htm

Agnew, D. J., Pearce, J., Pramod, G., Peatman, T., Watson, R., Beddington, J. R., et al. (2009). Estimating the worldwide extent of illegal fishing. PLoS ONE 4:e4570. doi: 10.1371/journal.pone.0004570

Alcala, A. C., and Russ, G. R. (2002). Status of Philippine coral reef fisheries. Asian Fish. Sci. 15, 177-192. Available online at: http://www.asianfisheriessociety.org/ publication/abstract.php?id=653

Allison, E. H., and Ellis, F. (2001). The livelihoods approach and management of small-scale fisheries. Mar. Policy 25, 377-388. doi: 10.1016/S0308597X(01)00023-9

Almany, G. R., Berumen, M. L., Thorrold, S. R., Planes, S., and Jones, G. P. (2007). Local replenishment of coral reef fish populations in a marine reserve. Science 316, 742-744. doi: 10.1126/science.1140597

Anticamara, J. A., Watson, R., Gelchu, A., and Pauly, D. (2011). Global fishing effort (1950-2010): trends, gaps, and implications. Fish. Res. 107, 131-136. doi: 10.1016/j.fishres.2010.10.016

Beddington, J. R., Agnew, D. J., and Clark, C. W. (2007). Current problems in the management of marine fisheries. Science 316, 1713-1716. doi: $10.1126 /$ science. 1137362

BFAR (2011). Philippine Fisheries Profile 2011. Available online at: http://www.bfar. da.gov.ph/files/img/photos/2011FisheriesProfile(Final)(4).pdf

Branch, T. A., Jensen, O. P., Ricard, D., Ye, Y., and Hilborn, R. (2011). Contrasting global trends in marine fishery status obtained from catches and from stock assessments. Conserv. Biol. 25, 777-786. doi: 10.1111/j.1523-1739.2011.01687.x

Branch, T. A., Watson, R., Fulton, E. A., Jennings, S., McGilliard, C. R., Pablico, G. T., et al. (2010). The trophic fingerprint of marine fisheries. Nature 468, 431-435. doi: 10.1038/nature09528

Briones, R. M. (2007). Eating for a lifetime: filling the policy gaps in Philippine fisheries. Asian J. Agric. Dev. 4, 25-39. Available online at: http://searca.org/ ajad/index.php/read-articles

Cabral, R., Cruz-Trinidad, A., Geronimo, R., Napitupulu, L., Lokani, P., Boso, D., et al. (2013). Crisis sentinel indicators: averting a potential meltdown in the Coral Triangle. Mar. Policy 39, 241-247. doi: 10.1016/j.marpol.2012. 10.012

Christie, P., Lowry, K., White, A. T., Oracion, E. G., Sievanen, L., Pomeroy, R. S., et al. (2005). Key findings from multidisciplinary examination of integrated coastal managgement process sustainability. Ocean Coast. Manag. 48, 468-483. doi: 10.1016/j.ocecoaman.2005.04.006

Cinner, J. E., McClanahan, T. R., MacNeil, M. A., Graham, N. A. J., Daw, T. M., Mukminin, A., et al. (2012). Comanagement of coral reef social-ecological systems. Proc. Natl. Acad. Sci. U.S.A. 109, 5219-5222. doi: 10.1073/pnas

FAO (2001). Production, Accessibility, Marketing and Consumption Patterns of Freshwater Aquaculture Products in Asia: a Cross-Country Comparison. Rome: FAO.

FAO (2012). The State of World Fisheries and Aquaculture. Rome: Food and Agriculture Organization of the United Nations.

FAO Fisheries and Aquaculture Department (2014). Global Capture Production Statistics 2012. Available online at: http://ftp.fao.org/FI/STAT/Overviews/ CaptureStatistics2012.pdf

Froese, R., Zeller, D., Kleisner, K., and Pauly, D. (2012). What catch data can tell us about the status of global fisheries. Mar. Biol. 159, 1283-1292. doi: 10.1007/s00227-012-1909-6

Go, K. T. B., Anticamara, J. A., de Ramos, J. A. A., Gabona, S. F., Agao, D. F., Herrera, E. C., et al. (2015). Species richness and abundance of non-cryptic fish species in the Philippines: a global center of reef fish diversity. Biodivers. Conserv. 24, 2475-2495. doi: 10.1007/s10531-015-0938-0

Harrison, H. B., Williamson, D. H., Evans, R. D., Almany, G. R., Thorrold, S. R., Russ, G. R., et al. (2012). Larval export from marine reserves and the recruitment benefit for fish and fisheries. Curr. Biol. 22, 1023-1028. doi: 10.1016/j.cub.2012.04.008

Hilborn, R., and Ovando, D. (2014). Reflections on the success of traditional fisheries management. ICES J. Mar. Sci. 71, 1040-1046. doi: 10.1093/icesjms/fsu034
Jelks, H. L., Walsh, S. J., Burkhead, N. M., Contreras-Balderas, S., Diaz-Pardo, E., Hendrickson, D. A., et al. (2008). Conservation status of imperiled North American freshwater and diadromous fishes. Fisheries 33, 372-407. doi: 10.1577/1548-8446-33.8.372

Johnson, A. E., Cinner, J. E., Hardt, M. J., Jacquet, J., Mcclanahan, T. R., and Sanchirico, J. N. (2013). Trends, current understanding and future research priorities for artisanal coral reef fisheries research. Fish Fish. 14, 281-292. doi: 10.1111/j.1467-2979.2012.00468.x

Juan-Jorda, M. J., Mosqueira, I., Cooper, A. B., Freire, J., and Dulvy, N. K. (2011). Global population trajectories of tunas and their relatives. Proc. Natl. Acad. Sci. U.S.A. 108, 20650-20655. doi: 10.1073/pnas.1107743108

Lebel, L., Anderies, J. M., Campbell, B., Folke, C., Hatfield-Dodds, S., Hughes, T. P., et al. (2006). Governance and the Capacity to Manage Resilience in Regional Social-Ecological Systems. 11:19. Available online at: http://www. ecologyandsociety.org/vol11/iss1/art19/

Maypa, A. P., Russ, G. R., Alcala, A. C., and Calumpong, H. P. (2002). Long-term trends in yield and catch rates of the coral reef fishery at Apo Island, Philippines. Mar. Freshw. Res. 53, 207-213. doi: 10.1071/MF01134

Muallil, R. N., Cabral, R. B., Mamauag, S. S., and Alino, P. M. (2012). "Status, trend and sustainability of small-scale fisheries in the Philippines," in Proceedings of the 12th International Coral Reef Symposium, Cairns, Australia, 9-13 July 2012 (Cairns, QLD), 5.

Muallil, R. N., Cleland, D., and Aliño, P. M. (2013). Socioeconomic factors associated with fishing pressure in small-scale fisheries along the West Philippine Sea biogeographic region. Ocean Coast. Manag. 82, 27-33. doi:10.1016/j.ocecoaman.2013.04.013.

Muallil, R. N., Mamauag, S. S., Cababaro, J. T., Arceo, H. O., and Aliño, P. M. (2014a). Catch trends in Philippine small-scale fisheries over the last five decades: the fishers $\times$ perspectives. Mar. Policy 47, 110-117. doi: 10.1016/j.marpol.2014.02.008

Muallil, R. N., Mamauag, S. S., Cabral, R. B., Celeste-Dizon, E. O., and Aliño, P. M. (2014b). Status, trends and challenges in the sustainability of smallscale fisheries in the Philippines: Insights from FISHDA (Fishing Industries' Support in Handling Decisions Application) model. Mar. Policy 44, 212-221. doi: 10.1016/j.marpol.2013.08.026

Musick, J. A., Harbin, M. M., Berkeley, S. A., Burgess, G. H., Eklund, A. M., Findley, L., et al. (2000). Marine, estuarine, and diadromous fish stocks at risk of extinction in North America (Exclusive of Pacific Salmonids). Fisheries 25, 6-30. doi: 10.1577/1548-8446(2000)025<0006:meadfs > 2.0.co;2

Myers, R. A., and Worm, B. (2003). Rapid worldwide depletion of predatory fish communities. Nature 423, 280-283. doi: 10.1038/nature01610

NSO (2014). National Quickstat March 2014. Manila. Available online at: http://www.census.gov.ph/sites/default/files/attachments/ird/quickstat/ March2014b_0.xls

Pauly, D. (1990). On malthusian overfishing. Naga ICLARM Q. 13, 3-4.

Pauly, D. (2009). Beyond duplicity and ignorance in global fisheries. Sci. Mar. 73, 215-224. doi: 10.3989/scimar.2009.73n2215

Pauly, D., Christensen, V., Guenette, S., Pitcher, T. J., Sumaila, R. U., Walters, C. J., et al. (2002). Towards sustainability in world fisheries. Nature 418, 689-694. doi: $10.1038 /$ nature 01017

Pauly, D., Hilborn, R., and Branch, T. A. (2013). Fisheries: does catch reflect abundance? Nature 494, 303-306. doi: 10.1038/494303a

Pollnac, R. B., and Pomeroy, R. S. (2005). Factors influencing the sustainability of integrated coastal management projects in the Philippines and Indonesia. Ocean Coast. Manag. 48, 233-251. doi: 10.1016/j.ocecoaman.2005. 04.003

Pomeroy, R. S., Oracion, E. G., Pollnac, R. B., and Caballes, D. A. (2005). Perceived economic factors influencing the sustainability of integrated coastal management projects in the Philippines. Ocean Coast. Manag. 2005, 360-377. doi: 10.1016/j.ocecoaman.2005.04.010

Roberts, C. M., McClean, C. J., Veron, J. E. N., Hawkins, J. P., Allen, G. R., McAllister, D. E., et al. (2002). Marine biodiversity hotspots and conservation priorities for tropical reefs. Science 295, 1280-1284. doi: $10.1126 /$ science. 1067728

Russ, G. R., and Alcala, A. C. (1999). Management histories of Sumilon and Apo Marine Reserves, Philippines, and their influence on national marine resource policy. Coral Reefs 18, 307-319. doi: 10.1007/s003380050203 
Russ, G. R., and Alcala, A. C. (2003). Marine reserves: rates and patterns of recovery and decline of predatory fish, 1983-2000. Ecol. Appl. 13, 1553-1565. doi: 10.1890/01-5341

Russ, G. R., and Alcala, A. C. (2004). Marine reserves: long-term protection is required for full recovery of predatory fish populations. Oecologia 138, 622-627. doi: 10.1007/s00442-003-1456-4

Russ, G. R., Alcala, A. C., Maypa, A. P., Calumpong, H. P., and White, A. T. (2004). Marine reserve benefits local fisheries. Ecol. Appl. 14, 597-606. doi: 10.1890/03-5076

Sadovy, Y. (2005). Trouble on the reef: the imperative for managing vulnerable and valuable fisheries. Fish Fish. 6, 167-185. doi: 10.1111/j.1467-2979.2005. 00186.x

Samoilys, M. A., Martin-Smith, K. M., Giles, B. G., Cabrera, B., Anticamara, J. A., Brunio, E. O., et al. (2007). Effectiveness of five small Philippines' coral reef reserves for fish populations depends on site-specific factors, particularly enforcement history. Biol. Conserv. 136, 584-601. doi: 10.1016/j.biocon.2007.01.003

San Diego, T.-J. A., and Fisher, W. L. (2014). Trends in the capture fisheries in Cuyo East Pass, Philippines. Int. J. Fish. Aquat. Stud. 1, 57-72. Available online at: http://www.fisheriesjournal.com/vollissue3/14.1.html

Silvestre, G. T., Garces, L. R., Stobutzki, I., Ahmed, M., Santos, R. A. V., Luna, C. Z., et al. (eds.). (2003). "South and South-East Asian coastal fisheries: their status and directions for improved management: conference synopsis and recommendations," in Assessment, Management and Future Directions for Coastal Fisheries in Asian Countries (Penang: WorldFish Center Conference Proceedings), 1-40. Available online at: http://aquaticcommons. $\operatorname{org} / 1282 /$
Stobutzki, I. C., Silvestre, G. T., Abu Talib, A., Krongprom, A., Supongpan, M., Khemakorn, P., et al. (2006). Decline of demersal coastal fisheries resources in three developing Asian countries. Fish. Res. 78, 130-142. doi: 10.1016/j.fishres.2006.02.004

Toribio, M. Z., Arceo, H. O., and Aliño, P. (2013). "Sharing the costs and benefits of marine protected areas: implications for good coastal resource governance," in Governing the Provision of Ecosystem Services, eds R. Muradian and L. Rival (Dordrecht: Springer Science+Business Media), 149-169.

Worm, B., and Branch, T. A. (2012). The future of fish. Trends Ecol. Evol. 27, 594-599. doi: 10.1016/j.tree.2012.07.005

Worm, B., Hilborn, R., Baum, J. K., Branch, T. A., Collie, J. S., Costello, C., et al. (2009). Rebuilding global fisheries. Science 325, 578-585. doi: $10.1126 /$ science. 1173146

Conflict of Interest Statement: The authors declare that the research was conducted in the absence of any commercial or financial relationships that could be construed as a potential conflict of interest.

The reviewer SF declares that, despite sharing an affiliation with co-author $\mathrm{KG}$, the review process was handled objectively and no conflict of interest exists.

Copyright (c) 2016 Anticamara and Go. This is an open-access article distributed under the terms of the Creative Commons Attribution License (CC BY). The use, distribution or reproduction in other forums is permitted, provided the original author(s) or licensor are credited and that the original publication in this journal is cited, in accordance with accepted academic practice. No use, distribution or reproduction is permitted which does not comply with these terms. 